\title{
The Best is yet to come - New drugs in Haematology
}

\author{
W. Willenbacher \\ Internal Medicine V, Hematology and Oncology, Medical University of Innsbruck, Innsbruck, Austria
}

In 1995 Edrecolomab (17-1A Panorex ${ }^{\circ}$ [1] was the first monoclonal antibody to be (at least temporarily) approved for cancer treatment (adjuvant CRC). The first intelligently designed small molecule (Imatinib - Glivec ${ }^{\circ}$ ) followed in 2001 [2] and, turning out to be a blockbuster, stimulated research and development in the field tremendously. While not every compound tested held its initial promises (e.g. Edrecolomab [3], Geftinib [4]) some turned to be big life-savers even seen from a global perspective (e.g. Trastuzumab [5], Rituximab [6], Imatinib [2], Bortezomib [7], Lenalidomid [8]) improving response rates, progression free, as well as overall survival rates and ultimately cure rates in a broad variety of malignant diseases previously uniformly judged to be fatal and boring to treat.

Today, on the contrary, clinicians are faced with a real deluge of -mabs and -mibs difficult to keep in focus even for the experienced expert. In this situation MEMO could fortunately motivate some leading international specialists to give us concise and thoughtful reviews of new drugs to be expected soon to enter every day clinical care in the fields of AML [9], ALL [10], NHL [11] and CMPDs [12]. From this series of articles we can easily approximate further clinically meaningful progress in all these entities in the near future. These findings are corroborated by exciting new evidence from the recent meetings in San Francisco (ASH) and San Antonio (Breast Cancer) [13].

This estimation is based not only on the sheer number of compounds investigated in Phase II and III studies worldwide but also on the ever more refined modes of drug development. Second generation antibodies with optimized binding capacities, targeted immuno- and radiotoxins, biand trifunctional and BiTE antibodies $[14,15]$ are only examples of this ongoing process of drug delivery and potency optimisation. On the other hand, improving biological understanding of mechanisms of disease and the generation of prospective and even more important predictive factors has made considerable progress, using methods as diverse as the development of clinical registries, cytogenetics, biomathematical scoring systems, proteomics and gene expression profiling, leading the way to a future not only targeted but also personalized evidence based medicine. Only the development of such personalisation tools as a co-operative, multidisciplinary, global group effort of the scientific and pharmaceutical

Correspondence: W. Willenbacher, MD, Internal Medicine V, Hematology and Oncology, Medical University of Innsbruck, Anichstraße 35, 6020 Innsbruck, Austria. E-mail: Wolfgang.Willenbacher@uki.at community can potentially guarantee that access to high quality medical care can be kept equal and health economically affordable.

So we have good reasons to hope that "the best is yet to come" and all are called to actively participate in this challenge (e.g. enrolling pts. in clinical trial whenever possible, participate in clinical registries, etc.) on any given opportunity.

Conflict of interest

The authors declare that there is no conflict of interest.

\section{References}

[1] Riethmüller G, Schneider-Gädicke E, Schlimok G, Schmiegel W, Raab R, Höffken K, Gruber R, Pichelmaier H, Hirche H, Pichelmayr R, Buggisch P, Witte J and the Deutsche Krebshilfe 17-1A Studiengruppe. Randomised trial of monoclonal antibody for adjuvant therapy of resected Dukes C colorectal carcinoma. Lancet, 343: 1177-1183, 1994.

[2] Druker BJ, Talpaz M, Resta DJ, Peng B, Buchdunger E, Ford JM, Lydon NB, Kantarjian H, Capdeville R, Ohno-Jones S, Sawyers CL. Efficacy and safety of a specific inhibitor of the BCR-ABL tyrosine kinase in chronic myeloid leukemia. NEJM, 344(14): 1031-1037, 2001.

[3] Punt C, et al. Edrecolomab alone or in combination with fluoruracilan $\mathrm{d}$ folinic acidin the adjuvant treatment of stage III colon cancer. Randomised study. Lancet, 360: 671-677, 2002.

[4] http://www.cancer.gov/ncicancerbulletin/NCI_Cancer_Bulletin_ 030805/page2

[5] Piccart-Gebhart MJ, Proctor M, Leyland-Jones B, et al. Trastuzumab after adjuvant chemotherapy in Her2-positive breast cancer. NEJM, 353: 1659-1672, 2005.

[6] Hiddemann W, Knebam M, Dreyling M, Schmitz N, Lengfelder E, Schmits R, Reiser M, Metzner B, Harder H, Hegewisch-Becker S, Fischer T, Kropff M, Reis HE, Freund M, Wormann B, Fuchs R, Planker M, Schimke J, Eimermacher H, Trümper L, Aldaoud A, Parwaresch R, Unterhalt M. Front-line therapy with rituximab added to the combination of cyclophosphamide, doxorubicin, vincristine and prednisone (CHOP) significantly improves the outcome of patients with advanced stage follicular lymphomas as compared to CHOP alone - results of a prospective randomized study of the German low grade lymphoma study group (GLSG). Blood, 106: 3725-3732, 2005.

[7] Richardson PG, Sonneveld P, Schuster MW, et al. Bortezomib or high-dose dexamethasone for relapsed multiple myeloma. NEJM, 352: 2487-2498, 2005.

[8] Chanan-Khan AA, Yu Z, Weber D, Chen C, Niesvizky R, Spencer A, Attal M, Belch A, Prince M, Olesnyckyj M, Knight, R, Zeldis J, Dimopoulos M. Lenalidomide (L) in combination with dexamethasone (D) significantly improves time to progression (TTP) in non-stem cell transplant patients (pts) with relapsed or refractory (rel/ref) multiple myeloma (MM): analysis from MM-009 and MM010 randomized phase III clinical trials. Blood, 108(S): abstr 3554, 2006.

[9] Schlenk R, Kayser S. New drugs in the treatment of acute myeloid leucemia. memo, 2: 75-79, 2009. 


\section{editorial}

[10] Gökbuget N, Wassmann B. New approaches to the treatment of adult acute lymphoblastic leukaemia. memo, 2: 80-88, 2009.

[11] Kassam S, Montoto S. New treatment options for the management of non-Hodgkin Lymphoma. memo, 2: 94-99, 2009.

[12] Webersinke G, Rumpold H. Pathogenetic and clinical impact of JAK2 mutations in chronic myeloproliferative diseases. memo, 2: 89-93, 2009.

[13] Mlineritsch B. News from endocrine treatment in breast cancer from the San Antonio Breast Cancer Symposium 2008. memo, 2: 110-112, 2009 .
[14] Reichert JM, Valge-Archer VE. Development trends for monoclonal antibody cancer therapeutics. Nat Rev Drug Discov, 6: 349-356 2007.

[15] Bargou R, Leo E, Zugmaier G, Klinger M,Goebeler M, Knop S, Noppeney R, Viardot A, Hess G, chuler M, Einsele H, Brandl, Wolf A Kirchinger P, Klappers P, Schmidt M, Riethmüller G, Reinhardt C, Baeuerle PA, Kufer P. Tumor regression in cancer patients by very low doses of a T cell-engaging antibody. Science, 321: 974-977, 2008. doi: 10.1126/science.1158545. 